\title{
MSE Competitive Business Strategies Typology: A Theory for Superior Performance
}

\author{
Madara M. Ogot ${ }^{1}$ \\ ${ }^{1}$ Professor, School of Business, University of Nairobi, Nairobi, Kenya \\ Correspondence: Prof. Madara M. Ogot, School of Business, University of Nairobi, Nairobi, Kenya.
}

Received: January 29, $2020 \quad$ Accepted: April 17, $2020 \quad$ Online Published: April 23, 2020

doi:10.5539/ibr.v13n5p69 URL: https://doi.org/10.5539/ibr.v13n5p69

\begin{abstract}
Micro and small enterprises (MSEs) are the engine that drives most of the economies in the developing world where they are often the largest employers. The MSE Typology presented in Ogot (2012), based on orthogonal constructs of collaboration and competency, combined to create a unique set of ideal types defining competitive business strategies MSEs can employ for superior performance. This paper establishes that the typology can be viewed as a theory for better performance tailored to MSEs. It goes further to present the research gaps that need to be addressed.
\end{abstract}

Keywords: business strategies, micro-enterprises, business performance, typology, theory-building

\section{Introduction}

Micro and small enterprises are significant contributors to economies around the world, and especially in developing countries. For example, in Ethiopia, MSEs are the second-largest employer next to agriculture (Abay et al., 2014). In Kenya, jobs in the informal sector, nearly all of whom are MSEs, constituted 83.6 per cent of total formal employment (KNBS, 2019), underscoring the key role they play. MSEs, however, face numerous challenges to success including competition, high cost of production, lack of adequate capital, and lack of ready markets (Ogot, 2014).

Ogot (2012) presented a typology of competitive business strategies for micro and small enterprises. The typology defined a set of generic strategy groups (ideal types) propositioned to lead to better performance. A typology is "a conceptually derived interrelated set of ideal types ... each which represents a unique combination of organisational attributes that are believed to determine the relevant outcomes" (Doty and Glick, 1994, p. 232). Generic strategies are applicable across industry, firm type, and firm size. Typologies provide a framework that classifies explicitly defined, quantifiable constructs, with articulated relationships between them and testable related predictions that are subject to disconfirmation (Snow and Kretchen, 2014).

A theory may be defined as a supposition or a system of ideals intended to explain something based on general principles independent of the thing to be explained. From the literature, there is a consensus view that a complete theory must have four key elements that answer the following questions: (a) What? (b) How? (c) Why? and (d) Who, where and when? (Whetten, 1989). The questions constitute a "statement of relations within a set of boundary assumptions and constraints" (Bacharach, 1989, p. 496).

The What question seeks to identify the factors that form part of the theory. Factors include variables, constructs, and concepts, with each individually adding value to the understanding derived from the theory (Whetten, 1989). Constructs and concepts, for example, culture and satisfaction, cannot be observed directly. Variables, for example, age and gender can (Bacharach, 1989). The relationship between the factors answers the How question and addresses any causality between them. Specifically, propositions define the relationship between constructs, while the hypotheses (derived from the propositions) define the relationships between variables.

The Why and How questions combined define or describe the domain of the theory. The rationale for the selection of the factors and their proposed causal relationships form the theory's underlying assumptions. They explain the theory and address the Why question. Finally, the Who, where and when questions place limitations on the theoretical model. As temporal and contextual elements, they fix the boundaries of generalisation, thereby constituting the range of the theory. These elements are often established through empirical testing of the initial theoretical elements defined by What, How and Why questions (Whetten, 1989). Not all typologies form a 
theory. This paper, therefore, sets out to show that the MSE typology in Ogot (2012) forms a theory for superior performance of MSEs by establishing to what extent the typology addresses the four key elements that define a theory.

\section{Literature Review}

\subsection{The MSE Competitive Business Strategies Typology}

The MSE typology is based on the concepts of competency, collaboration and business performance (see Figure 1). MSEs may apply strategies that exploit combinations of competency and collaboration elements to become more competitive in the market, leading to better business performance. These combinations are formed around four constructs (ideal types) namely peer differentiation, peer low cost, mentor differentiation, and mentor low cost. Peer refers to collaborative activities carried out between MSEs within their networks and linkages. Collaborative activities through relationships with larger enterprises and organisations are mentor (Ogot, 2012).

Differentiation strategies aim to set an enterprise's products and services apart from their competitors within a localised market. On the other hand, low-cost strategies strive to reduce production and operating costs enabling the business to become more competitive by passing the savings to their customers. Business performance is a subset of organisational effectiveness. In its narrowest conception, business performance centres on the use of outcome-based financial indicators assumed to reflect the economic goals of the firm. A broader conceptualization of business performance may also include an emphasis on indicators of operational performance in addition to the indicators of financial performance (Venkatramen and Ramanjam, 1986).

\subsection{Typological Approach to Theory Building}

Typologies have been criticised in the literature for being more of classification schemes than theories (Rich, 1992). These critiques find credence from numerous descriptive typology presentations that do not develop any underlying theory. Doty and Glick (1994), however, disagree with this view arguing that,

"typologies are complex theories that are frequently misinterpreted ... the problems with many existing typologies are the result of a misunderstanding about what typologies are (or should be), improper development of the typology, and a failure to take full advantage of the unique form of theory building represented by the typology approach."

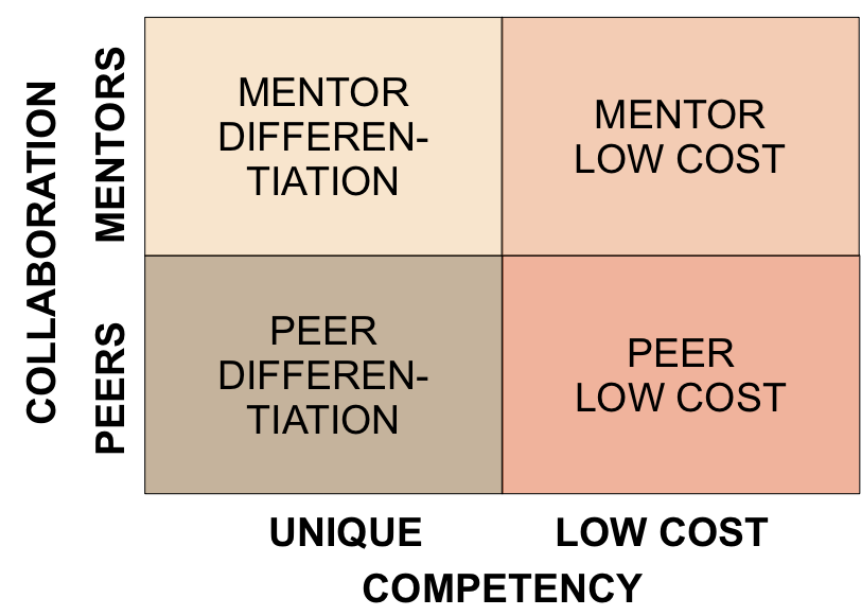

Figure 1. MSE Competitive Business Strategies Typology

Source: Ogot (2012)

Biggart and Delbridge (2004) posit that typologies provide a key tool to theorists making distinctions between complex phenomena. O'Raghallaigh, Sammon and Murphy (2010) conclude that typologies meet all four properties of 'good' theory namely having constructs, predict relationships among the constructs, predictions are falsifiable, and domain limitation. Fiss (2011) posits that typologies lend themselves to development of configurational arguments by incorporating notions of equifinality and asymmetric causal relations, as opposed to simple correlations. Also, Delbridge and Fiss (2013) state that typologies are complex systems of theoretical statements, presenting a challenging and attractive form of theorising. The ideal type construct in typologies can 
be used to represent holistic configurations of unidimensional constructs and are theoretical abstractions posited to yield a specified level of a dependent variable. They are often described in terms of multiple dimensions representing different concepts ${ }^{1}$ (though not necessarily existing) in organisations and integrate multiple organisational attributes into a holistic definition of fit (Doty \& Glick, 1994).

What constitutes a theory? What criteria must a theory meet to be considered a theory? Although there is no universal agreement, there is consensus on three criteria: (a) identified and articulated constructs, (b) relationships between the constructs must be specified, and (c) the relationships must be subject to empirical validation (Whetten, 1989). The two main criteria on which any theory can be evaluated are falsifiability and utility. Falsifiability establishes whether a theory is set up so that it can be empirically refuted, supporting the consensus view that theories can never be proven but only disproven. Utility addresses the usefulness of the theory, that is, its ability to both explain and predict. "An explanation establishes the substantive meaning of constructs, variables, and their linkages, while prediction tests the substantive meaning by comparing it to empirical evidence." (p. 501)

\section{Is the MSE Typology a Complete Theoretical Framework}

This paper sets out to establish to what extent the MSE typology answers the What? How? Why? and Who, where and when? questions to be considered a theory.

\subsection{Does the MSE Typology Address the What Question?}

The what question establishes the variables, constructs, and concepts that collectively form the theory. For the MSE typology, the variables that provide measurability associated with the peer differentiation, peer low cost, mentor differentiation and mentor low-cost constructs were presented in Ogot (2012) and Ogot et al. (2018a). The lists, which are not exhaustive, were based on a review and synthesis of the MSE literature. In typology development and from the initial ideal types, combinations (referred to as hybrids) can be derived creating new ideal types that are conceptually and analytically equivalent to the initial types (Doty and Glick, 1994). One approach to establishing the hybrid types is to determine all the combinations based on the extent (using a low, high and medium rating) that an enterprise may apply in combination, any of the pure ideal types (PertusaOrtega, Molina-Azorin, and Claver-Cortes, 2009). Using this approach and with reference to Table 1, an analysis of the MSE typology yielded eleven hybrid types, that in conjunction with the four pure types brings the total number of ideal types to fifteen (Ogot et al. 2018b).

Table 1. Pure and Hybrid Ideal Types in the MSE Model

\begin{tabular}{|c|c|c|c|c|l|}
\hline No. & PLC & PD & MLC & MD & \multicolumn{1}{|c|}{ Strategy Ideal Type } \\
\hline 1 & H & L & L & L & Pure Peer Low Cost \\
2 & L & H & L & L & Pure Peer Differentiation \\
3 & L & L & H & L & Pure Mentor Low Cost \\
4 & L & L & L & H & Pure Mentor Differentiation \\
5 & H & L & H & L & Hybrid Low Cost \\
6 & $\mathrm{~L}$ & H & L & H & Hybrid Differentiation \\
7 & $\mathrm{H}$ & H & L & L & Hybrid Peer \\
8 & $\mathrm{~L}$ & $\mathrm{~L}$ & $\mathrm{H}$ & $\mathrm{H}$ & Hybrid Mentor \\
9 & $\mathrm{~L}$ & $\mathrm{H}$ & $\mathrm{H}$ & $\mathrm{L}$ & 2-Dimension Mixed \\
10 & $\mathrm{H}$ & $\mathrm{L}$ & $\mathrm{L}$ & $\mathrm{H}$ & 2-Dimension Mixed \\
11 & $\mathrm{H}$ & $\mathrm{H}$ & $\mathrm{H}$ & $\mathrm{L}$ & Broad Hybrid \\
12 & $\mathrm{H}$ & $\mathrm{L}$ & $\mathrm{L}$ & $\mathrm{H}$ & Broad Hybrid \\
13 & $\mathrm{H}$ & $\mathrm{H}$ & $\mathrm{H}$ & $\mathrm{H}$ & Broad Hybrid \\
14 & $\mathrm{~L}$ & $\mathrm{H}$ & $\mathrm{H}$ & $\mathrm{H}$ & Broad Hybrid \\
15 & $\mathrm{H}$ & $\mathrm{H}$ & $\mathrm{H}$ & $\mathrm{H}$ & Broad Hybrid \\
$16-27$ & $\mathrm{M} / \mathrm{L}$ & $\mathrm{M} / \mathrm{L}$ & $\mathrm{M} / \mathrm{L}$ & $\mathrm{M} / \mathrm{L}$ & Stuck-in-the-middle \\
\hline
\end{tabular}

Key: PLC-Peer Low Cost, PD- Peer Differentiation, MLC-Mentor Low Cost, MD-Mentor Differentiation, LLow, M-Medium, H-High

To test the content validity of the variables in the MSE typology, Ogot et al. (2018a) carried out a study among manufacturing micro-enterprises in Nairobi. Using Pearson's correlations between pairs of variables defining

\footnotetext{
${ }^{1}$ Dimensions are also referred to in the literature as "first-order" constructs.
} 
each of the four pure ideal types, they found coefficients ranging between 0.19 to 0.84 , all significant with pvalues $<0.0001$. Also, the underlying variables for all four ideal types yielded Cronbach $\alpha$ 's ranging between 0.8519 to 0.9592 , suggesting high internal consistency and thus high reliability of the data collected based on the chosen variables (Nunnally, 1978). A good choice of variables (strategies in our context) should be generally applicable across industry, organisation type or size (Herbert \& Deresky, 1989). Although limited in scope, Ogot et al. (2018a) carried out an investigation into the generality of the typology variables across two sub-sectors (furniture manufacturing and agro-food processing) and between genders (taken as male and female). Using binary logistic regression, they found that none of the variables served as statistically significant discriminants between male or female owners.

Across sub-sectors, only two of the twenty-eight variables were statistically significant, albeit mild, discriminants. Specifically, the odds of an agro-food processing business adopting the strategy "I work with larger business to get new technologies to help me develop new products" was significant and 1.742 times higher than for a manufacturing business. Although not precluding the generalisability of the strategy, the result did show a preference by agro-food processing MSEs. This may be due to the ease of obtaining small-scale food processing equipment along with the requisite training from the vendors (larger enterprises) who are often promoting the new equipment and the introduction of new approaches to food processing. In addition, at the MSE level, new technologies for agro-food processing often cost less and are easier to access through relationships with vendors, than equipment for manufacturing. The odds of manufacturing businesses adopting the strategy defined "Through my membership, I have been able to exchange ideas with other business owners that have helped me develop new products," was significant and 1.740 times higher than for agro-food processing businesses. Although business associations are found across both sub-sectors, membership in them was found to be more prevalent among those in manufacturing than agro-food processing, explaining the higher odds.

The above discussion, therefore, presents initial support for the MSE typology meeting the 'What' criteria of a theory. A summary of the concepts, constructs, and variables is presented in Table 2.

\subsection{Does the MSE Typology Address the Why and the How Questions?}

Theorists must have a clear understanding of how a proposed theory fits within other preexisting theories. One aspect of fit is connectivity: the ability of the proposed theory to connect two or more existing theories, providing insights into the domains of the previous theories, thereby creating new knowledge (Bacharach, 1989). The MSE typology connects competitive business strategies theory developed by Porter (1980) and strategic alliance theories (Yoshino \& Rangan, 1995; Todeva \& Knoke, 2005) to achieve superior business performance (answer to the Why question).

The two main concepts of competency and collaboration upon which the MSE typology is built have strong theoretical underpinnings in the literature. Competency, based on the differentiation and low-cost leadership constructs, was first popularised by Porter $(1980,1985)$. Low-cost leadership is achieved by operating at lower costs than competitors and passing on the savings to the customer. Low-cost strategies success comes from achieving high volumes and operating with low margins. Differentiation targets above-average returns through unique products and services that are harder to copy and for which customers are willing to pay more. They achieve success from higher margins and lower volumes. Approaches to the implementation of both constructs, however, seem better suited to medium and larger companies who have more control of and access to resources (Porter, 1980, 1985; Kim, Nam \& Stimpert, 2004; Alpkan et al., 2005; Spanos, Zaralis \& Lioukas, 2004; PertusaOrtega et al. 2009) than MSEs. The Why question addressed by the MSE typology, therefore, is to make the constructs better suited for implementation by MSEs. 
Table 2. Summary of Concepts, Constructs and Variables in the MSE Model

\section{Construct (Concept(s)/Variables}

Construct: Peer Differentiation

(Concepts: Collaboration and Competency)

- Group development of new products

- Quality compliance through producer groups

- Group labour specialization

- Joint problem solving

- Group lending/borrowing

\section{Construct: Mentor Differentiation}

(Concepts: Collaboration and Competency)

- Branding through mentor organisations

- Technology transfer from forward/backward linkages generating new product

- development

- Access finance and/or credit through forward/backward linkages

- Sub-contracting

- Backward/forward linkages for training

- $\quad$ Backward linkages for specialized inputs

- Access to lower cost finance and/or credit through membership in umbrella organisations (associations) or cooperatives

- Technology transfer through umbrella organisations (associations) generating new product development

- Publicity, quality control, training and/or exchange of ideas through umbrella organisations (associations)

\section{Construct: Peer Low Cost}

(Concepts: Collaboration and Competency)

- Group bulk procurement of raw materials

- Group Lending/Borrowing

- Joint problem solving

- Reciprocal business relationships (for example, provision of material support,

- $\quad$ buying merchandise from each other)

- Sharing of workspaces and specialized equipment

- $\quad$ Participation in group bidding

\section{Construct: Mentor Low Cost}

(Concepts: Collaboration and Competency)

- Technology transfer to improve production efficiencies from forward/backward linkages

- Backward/forward linkages for training

- Access to lower cost finance and/or credit through forward/backward linkages

- Backward linkages for low-cost inputs

- Access to lower cost finance and/or credit membership in umbrella organisations (associations) or cooperatives

- Technology transfer to improve production efficiencies from umbrella organisations (associations)

- Access to lower cost raw materials through organisations (associations) who buy in bulk

- Training and/or exchange of ideas through umbrella organisations (associations)

\section{Construct: Business Performance}

(Concepts: Competitive Advantage)

- Revenue Growth

- Business Age

- $\quad$ Growth Number of Employees

Source: Ogot (2014)

A review of MSE literature suggests that inter-firm cooperation is key to success (Lange, Ottens \& Taylor, 2000; Propis, 2002; Wattanapruttipaisan, 2002; Kula et al, 2005; Makombe, 2006; Kabukuru, 2011). Firms may choose to collaborate to accrue tangible benefits, for example, higher profits, increased market share, and strengthened competitive advantage; or intangible benefits including the development of specific competencies or learning new skills (Simonin, 1997). Inter-firm cooperation is formed by at least two businesses who remain legally independent, share benefits and managerial oversight on agreed and assigned tasks, and make contributions in agreed-upon strategic areas (Yoshino \& Rangan, 1995). Businesses form strategic alliances for a diversity of reasons, where decisions "to cooperate [is] not a responsive action, but is fundamentally a strategic intent, which aims at improving the future circumstances for each firm and their partnership as a whole" (Todeva \& Knoke, 2005, p. 129). 
From a resource-based view, strategic alliances are formed when both firms require resources and/or posses valuable resources to share (Eisenhardt \& Schoonhoven, 1996). Alliances serve as a vehicle for obtaining otherwise unattainable competitive advantages and value to the firm (Das \& Teng, 2000). This is especially important for small businesses who often lack resources to adequately respond to threats or take advantage of available opportunities (Palakshappa \& Gordon, 2007). Further, firms may join umbrella trade organisations to seek additional resources and capabilities, especially MSEs, who lack significant internal resources and capabilities. This leads to the first proposition addressing the Why question:

$P_{1}$ : MSEs can achieve better business performance through collaborative strategies with their peers and with larger organisations (mentors).

The MSE typology provides 28 possible strategies (Ogot, 2012) for superior business performance. From questionnaires administered to manufacturing MSEs in Nairobi, Ogot et al. (2018a) found that membership in umbrella trade organisations (categorised under mentor collaborations) emerged as the most significant form of collaboration. Also, strategies seeking to accrue resources and capabilities from membership in umbrella organisations formed eight of the top ten strategies. There is significant importance attached by MSEs to improved competitive advantage and performance through membership. This view is supported by Hardy et al. (2003) who contend that inter-firm collaboration leads to increased collective learning, providing opportunities for development and exchange of ideas, aspects central to umbrella organisations. A similar outcome was found by Makombe (2005) among Tanzanian women MEs. This leads to the next set of propositions addressing the How question:

\section{$P_{2 a}$ : The MSE typology can serve as determinants of strategic group membership among MSEs.}

$P_{2 a}$ focuses on determining the extent MSEs employ strategies similar to the MSE typology ideal types, enabling falsifiability, a key requirement of a theory. MSEs who employ strategies defined within any of the fifteen ideal types are said to be members of that strategic group. If they do not employ any, they are categorised as "stuck-inthe-middle" (Porter, 1985). Ogot et al. (2018b) carried out an exploratory survey among manufacturing and agrofood processing MSEs in Nairobi. They found significant differences (all with $p<0.0000$ ) between MSEs that were members of the different strategic groups, confirming the validity of the proposed ideal types. Based on the variables presented in Table 2, Ogot et al. (2018b) found that a majority, 109 businesses, were members of the strategic group defined by the Broad Hybrid ideal type with twenty-eight business not belonging to any group, or "stuck-in-the-middle."

That membership in a strategic group can lead to better performance forms the basis of the following two propositions:

\section{$P_{2 b}$ : MSEs employing strategies to be similar to a pure ideal type in the MSE typology, leads to superior business performance \\ $P_{2 c}:$ MSEs employing strategies to be similar to a hybrid ideal type in the MSE typology, leads to superior business performance.}

Using Binary logistic regression on the same population of manufacturing and agro-food processing MSEs, Ogot et al. (2018b) found that only members of the strategic group defined by the peer differentiation pure ideal type had superior business performance than those stuck-in-the-middle. Though the lack of significant performance differences between businesses in strategic groups defined by the other pure ideal types did not support $P_{2 b}$, it did not falsify it either, leaving room for further investigation. For the hybrid ideal types $\left(P_{2 c}\right)$, MSEs who were members of the strategic groups defined by the broad hybrid, hybrid differentiation and hybrid mentor ideal types had better business performance than those stuck-in-the- middle, providing support to $P_{2 c}$. Businesses who were members of strategic groups defined by the hybrid low cost and the hybrid peer did not exhibit a significant performance difference with those stuck-in-the-middle. The lack of significant performance differences although not in support of $P_{2 c}$, does not falsify it, leaving room for further investigation.

\subsection{Does the MSE Typology Address the Who, Where, When Questions?}

Answers to the who, where and when questions provide temporal and contextual elements that fix boundaries and establish the range of the theory. These are established through empirical testing on different populations, regions and contexts. Studies by Ogot et al. (2018a, 2018b), for example, begun to establish these boundaries. They used the Government of Kenya definition for 'micro' and 'small' in the Micro and Small Enterprises Act (2012) where a microenterprise is defined as a firm, trade, service industry or business activity whose annual turnover does not exceed Kshs. 500,000 ( US\$5,000) and employs less than ten people. For those in the manufacturing sector, their investment in plant and machinery or its registered capital should not exceed Kshs 10 
million ( US $\$ 100,000)$. For the service sector and farming enterprises, the investment in equipment or its registered capital should not exceed Kshs. 5 million ( US\$50,000). A small enterprise is a firm, trade, service industry or business activity whose annual turnover ranges between Kshs. 500,000 (US\$5,000) and Kshs 5 million (US\$50,000), and employs between ten and fifty people. For those in the manufacturing sector, their investment in plant and machinery or its registered capital should range between Kshs. 10-50 million (US\$100,000 - US\$500,000). For the service sector and farming enterprises, the investment in equipment or its registered capital should range between Kshs 5-20 million (US\$50,000 - US\$200,000).

These definitions and the location of the study begins to establish the boundaries and provide answers to the who and where elements of the theory. Of course, other empirical studies will seek to further extend the boundaries of validity for the typology. Further, elements of the MSE typology were also identified in Prasad and Tata (2010). They found that inter-firm collaboration between silk sari micro-enterprises (MEs) led to a better understanding of their customer needs resulting in improved performance. Similarly, Ntseane (2004) found inter-firm collaboration between women MEs in Botswana significantly improved business performance. Their studies demonstrate that strategies that incorporate collaboration may result in better ME business performance. The when element for the MSE Typology remains to be explicitly investigated. When elements include product lifecycle, businesses life cycle and seasonality of products. These need to be addressed in future studies.

\section{Discussion}

The typology approach to theory building is a multidimensional view of a management or organisational subject (Cornelissen, 2017) and represent coherent accounts of complex cause and effect relationships (Fiss, 2011). Although there are sceptics to this approach to theory building, proponents have argued that "the value of a typology lies in its ability to clearly delineate constructs, and make falsifiable predictions concerning an outcome variable of interest" (Bilgili et al., 2020). The MSE Typology presents a framework for new insights into MSE research. These are summarised in Table 3, based upon O'Raghallaigh et al.'s (2010) framework for properties of theories. The typology provides a structured theoretical framework for the investigation of the performance of MSEs under different conditions and contexts, and may be better suited than those currently used in the literature that may not be well suited for analysis of or implementation by MSEs.

Going forward we encourage researchers to further define additional strategies that would fit within the pure ideal types to complement or replace the current twenty-eight. For example, little work has been done on dynamic capabilities-based approaches (Teece, 2007; Eisenhardt \& Martin, 2000; Pavlou \& Sawy, 2011) to superior performance in MSEs. Strategies defined through these approaches could be added to the existing set. Also, more empirical studies should be done to better understand and answer the Who, where and when questions. These studies would improve the typology and make its application more effective in improving the financial performance of MSEs.

Table 3. Summary of MSE Typology meeting the criteria of a theory

\begin{tabular}{|l|l|l|l|}
\hline $\begin{array}{c}\text { Property of } \\
\text { Theory }\end{array}$ & \multicolumn{1}{|c|}{$\begin{array}{c}\text { Description of } \\
\text { Property }\end{array}$} & \multicolumn{1}{c|}{ Mapping to Typology } & \multicolumn{1}{c|}{ MSE Typology } \\
\hline $\begin{array}{l}\text { Limitations of } \\
\text { domain }\end{array}$ & $\begin{array}{l}\text { Establishes the } \\
\text { domain limits for } \\
\text { that the theory } \\
\text { holds } \text { when and } \\
\text { where) }\end{array}$ & $\begin{array}{l}\text { Clarity of the intended purpose of the } \\
\text { typology theory and the situations the } \\
\text { predictions hold true. }\end{array}$ & $\begin{array}{l}\text { MSE typology seeks to provide fit among } \\
\text { the defined constructs leading to improve } \\
\text { competitive advantage and business } \\
\text { performance. }\end{array}$ \\
\hline $\begin{array}{l}\text { Conceptual } \\
\text { definitions }\end{array}$ & $\begin{array}{l}\text { What gets included } \\
\text { in the definition } \\
\text { (who and what })\end{array}$ & $\begin{array}{l}\text { Two distinct types of constructs are found } \\
\text { within typologies: } \\
\text { Ideal types - multi-dimensional } \\
\text { abstractions posited to yield a specified } \\
\text { dependent variable level. } \\
\text { Description of ideal types is in the } \\
\text { form of uni-dimensional constructs, } \\
\text { with each ideal type representing a } \\
\text { unique combination of the constructs }\end{array}$ & $\begin{array}{l}\text { The MSE typology describes ideal types } \\
\text { for MSEs for improved performance as } \\
\text { differentiation and mentor differentiation. }\end{array}$ \\
\hline $\begin{array}{l}\text { Building } \\
\text { relationships }\end{array}$ & $\begin{array}{l}\text { Provides a logical } \\
\text { relationship } \\
\text { between the } \text { why } \\
\text { and how constructs }\end{array}$ & $\begin{array}{l}\text { Typologies explain how and why the } \\
\text { construct patterns within an ideal type } \\
\text { result in the specified level of the } \\
\text { dependent variable(s). }\end{array}$ & $\begin{array}{l}\text { The MSE typology explains why higher } \\
\text { the similarity to the ideal types is } \\
\text { hypothesised to result in greater } \\
\text { performance. }\end{array}$ \\
\hline
\end{tabular}




\begin{tabular}{|l|l|l|l|}
\hline $\begin{array}{c}\text { Property of } \\
\text { Theory }\end{array}$ & \multicolumn{1}{|c|}{$\begin{array}{c}\text { Description of } \\
\text { Property }\end{array}$} & \multicolumn{1}{c|}{ Mapping to Typology } & \multicolumn{1}{c|}{ MSE Typology } \\
\hline $\begin{array}{l}\text { Making } \\
\text { predictions }\end{array}$ & $\begin{array}{l}\text { Provides, specific } \\
\text { testable predictions }\end{array}$ & $\begin{array}{l}\text { Hypothesised relationships on the degree of } \\
\text { similarity of an organisation to the ideal } \\
\text { types and the dependant variables(s) can be } \\
\text { derived from typologies. These predicted } \\
\text { relationships can be falsified. }\end{array}$ & $\begin{array}{l}\text { Through testable predictions, not all the } \\
\text { ideal types defined in the MSE typology } \\
\text { were found in the studies by Ogot et al } \\
\text { (2018a, 2018b) to result in superior } \\
\text { performance for the selected population. }\end{array}$ \\
\hline
\end{tabular}

\section{References}

Abay, H. H., Tessema, F., \& Gebreegziabher, A. (2014). External Factors Affecting the Growth of Micro and Small Enterprises (MSEs) in Ethiopia: A Case Study in Shire Indasselassie Town, Tigray. European Journal of Business and Management, 6(34), 134-145.

Alpkan, L., Bulut, C., \& Mert, E. (2005). Strategic Planning Trends in Turkish Small Firms: Empirical Study on SMEs in Kocadi. Proceedings of the International Strategic Management Congress. Canakkale, Turkey.

Bacharach, S. B. (1989). Organization Theories: Some Criteria for Evaluation. Academy of Management Review, 14(4), 495-515. https://doi.org/10.5465/amr.1989.4308374

Bilgili, H., Campbell, J., O'Leary-Kelly, A., Ellstrand, A., \& Johnson, J. (2020). The Final Countdown: Regulatory Focus and the Phases of CEO Retirement. Academy of Management, 45(1), 58-84. https://doi.org/10.5465/amr.2016.0455

Cornelissen, J. (2017). Editors Comment: Developing Propositions, a process model, or a Typology. Addressing the Challenges of Writing a Theory without a Boilerplate. Academy of Management Review, 42, 1-9. https://doi.org/10.5465/amr.2016.0196

Das, J. K., \& Teng, B. S. (2000). A Resource-Based Theory of Strategic Alliances. Journal of Strategic Management, 26(1), 31-36. https://doi.org/10.1016/S0149-2063(99)00037-9

Delbridge, R., \& Fiss, P. (2013). Editors' Comments: Styles of Theorizing and the Social Organization of Knowledge'. Academy of Management Review, 38(3), 325-331. https://doi.org/10.5465/amr.2013.0085

Doty, D. H., \& Glick, W. H. (1994). Typologies as a Unique Form of Theory Building: Toward Improved Understanding and Modeling. Academy of Management Review, 19, 230-251. https://doi.org/10.5465/amr.1994.9410210748

Eisenhardt, K. M., \& Martin, J. A. (2000). Dynamic Capabilities: What are they? Strategic Management Journal, 2l(10-11), 1105-1121. https://doi.org/10.1002/1097-0266(200010/11)21:10/11<1105::AID-SMJ133>3.0.CO;2-E

Eisenhardt, K. M., \& Schoonhoven, C. B. (1996). Resource-Based View of Strategic Alliance Formation: Strategic and Social Effects of Entrepreneurial Firms. Organization Science, 7, 136-150. https://doi.org/10.1287/orsc.7.2.136

Fiss, P. C. (2011). Building Better Causal Theories: A Fuzzy Set Approach to Typologies in Organisation Research. Academy of Management Journal, 54, 393-420. https://doi.org/10.5465/amj.2011.60263120

Hardy, C., Phillips, N., \& Lawrence, T. B. (2003). Resources, Knowledge and Influence: the Organizational Effects of Inter-Organizational Collaboration. Journal of Management Studies, 40(2), 321-347. https://doi.org/10.1111/1467-6486.00342

Herbert, T., \& Deresky, H. (1987). Generic strategies: An empirical investigation of typology validity and strategy content. Strategic Management Journal, 8(2), 135-147. https://doi.org/10.1002/smj.4250080205

Kim, L., \& Lim, Y. (1988). Environment, Generic strategies, and Performance in a rapidly developing country: A Taxonomic Approach. Academy of Management Journal, 31, 802-827. https://doi.org/10.5465/256339

KNBS. (2020). Economic Survey 2019, Nairobi: Kenya National Bureau of Statistics.

Kula, O., Choudhary, V., \& Batzdorff, L. (2005). Integrating micro- and small-scale enterprises into productive markets: A discussion paper. micro Report 20, US Agency for International Development (USAID).

Lange, T., Ottens, M., \& Taylor, A. (2000). SMEs and barriers to skills development: A Scottish perspective. Journal of European Industrial Training, 24(1), 5-11. https://doi.org/10.1108/03090590010308219 
Makombe, I. A. (2006). Women Entrepreneurship Development and Empowerment in Tanzania: The Case of SIDO/UNIDO- supported Women Micro-entrepreneurs in the Food Processing Sector (PhD thesis). University of South Africa.

Nunnally, J. (1978). Psychometric Theory. McGraw-Hill, New York.

O’Raghallaigh, P., Sammon, D., \& Murphy, C. (2010). Theory-building using typologies-A worked example of building a typology of knowledge activities for innovation. DSS, 371-382.

Ogot, M. (2012). A generic competitive business strategies typology for micro-enterprises. European Journal of Business Management, 4(20), 98-109.

Ogot, M. (2014). Evidence on Challenges Faced by Manufacturing Informal Sector Micro-Enterprises in Nairobi and their Relationship with Strategic Choice. International Business Research, 7(6). https://doi.org/10.5539/ibr.v7n6p119

Ogot, M. M., Awino, Z. B., \& Aosa, E. (2018a). Generic business strategies in the Micro and Small Enterprise typology: an empirical investigation among Nairobi Manufacturing Micro and Small Enterprises. African Journal of Business and Management, 4(2), 54-71.

Ogot, M. M., Awino, Z. B., \& Aosa, E. (2018b). Empirical validation of a Micro and Small Enterprises Typology: impact of performance on Micro and Small Enterprises in Nairobi. African Journal of Business And Management, 4(3), 14-31.

Palakshappa, N., \& Gordon, M. E. (2007). Collaborative Business Relationships: Helping Firms to Acquire Skills and Economies to Prosper. Journal of Small Business and Enterprise Development, 14(2), $264-279$. https://doi.org/10.1108/14626000710746691

Pavlou, P. A., \& El Sawy, O. A. (2011). Understanding the elusive black box of dynamic capabilities. Decision Sciences, 42(1), 239-273. https://doi.org/10.1111/j.1540-5915.2010.00287.x

Pertusa-Ortega, E., Molina-Azorin, J. F., \& Claver-Cortes, E. (2009). Competitive strategies and firm performance: A comparative analysis of pure, hybrid or "stuck in the middle" strategies in Spanish firms. British Journal of Management, 20, 508-523. https://doi.org/10.1111/j.1467-8551.2008.00597.x

Porter, M. E. (1980). Competitive strategy: Techniques for analyzing industries and competitors. The Free Press, New York.

Porter, M. E. (1985) Competitive advantage: Creating and sustaining superior performance. New York: The Free Press.

Propis, L. D. (2002). Types of innovation and inter-firm cooperation. Entrepreneurship and Regional Development, 14(4), 337-353. https://doi.org/10.1080/08985620210144974

Simonin, B. L. (1997). The Importance of Collaborative Know-how: An Empirical Test of the Learning Organization. Academy of Management Journal, 40(5), 1150-1174. https://doi.org/10.5465/256930

Snow, C., \& Ketchen, D. J. (2014). Typology driven theorizing: A response to Delbridge and Fiss, Academy of Management Review, 39(2), 231-233. https://doi.org/10.5465/amr.2013.0388

Spanos, Y. E., Zaralis, G., \& Lioukas, S. (2004). Strategy and industry effects on profitability: Evidence from Greece, Strategic Management Journal, 25(2), 139-165. https://doi.org/10.1002/smj.369

Teece, D. J. (2007). Explicating dynamic capabilities: the nature and microfoundations of (sustainable) enterprise performance. Strategic Management Journal, 28(13), 319-1350. https://doi.org/10.1002/smj.640

Todeva, E., \& Knoke, D. (2005). Strategic alliances and models of collaboration. Management decision, 43(1), 123-148. https://doi.org/10.1002/smj.369

Venkatraman, N., \& Ramanujam, V. (1986). Measurement of Business Performance in Strategy Research: A Comparison of Approaches. The Academy of Management Review, 11(4), 801-814. https://doi.org/10.5465/amr.1986.4283976

Wattanapruttipaisan, T. (2002). SME requirements as a bridgehead to competitiveness: An assessment of supplyside capabilities and demand-side requirements. Asia-Pacific Development Journal, 9(1), 65-87.

Whetten, D. A. (1989). What Constitutes a Theoretical Contribution. Academy of Management Review, 14, 490495. https://doi.org/10.5465/amr.1989.4308371 
Yoshino, M. Y., \& Rangan, U. S. (1995). Strategic Alliances: An Entrepreneurial Approach to Globalization. Harvard University Press, Cambridge, MA.

\section{Copyrights}

Copyright for this article is retained by the author(s), with first publication rights granted to the journal.

This is an open-access article distributed under the terms and conditions of the Creative Commons Attribution license (http://creativecommons.org/licenses/by/4.0/). 